\title{
Factors Affecting the Use of Information Technology in Thai Agricultural Cooperatives : A Work in Progress
}

\author{
Chieochan O., Lindley D. and Dunn T. \\ School of Information Studies, \\ Charles Sturt University, \\ Locked Bag 675, Wagga Wagga, \\ NSW 2678, Australia. \\ Email oran@csu.edu.au.
}

\begin{abstract}
This paper describes work in progress studying factors affecting the use of information technology in Thai agricultural cooperatives. Factors in the internal and external environment of organizations are considered. Factors from the internal environment are divided into 2 groups: characteristics of managers of Thai agricultural cooperatives (i.e. attitude towards adoption of IT, IT knowledge, and innovation), and organizational characteristics (i.e. business size, organizational structure, and organizational culture). General factors from the external environment are political, economic, social, and infrastructure. Methodology and its development are also described.
\end{abstract}

\section{Keywords}

Information technology, Thailand, agriculture, agricultural cooperatives.

\section{Introduction}

In Thailand, agricultural activities such as crop cultivation, livestock, fishery, and forestry are important to the national economy. Agriculture contributes about 17 percent to Thai GNP and is about 34 percent of all exports (Mahidol University, 1998). In 1991, about 62\% of the Thai population, approximately 36 million people, were involved in agriculture (Office of Agriculture Economic, Ministry of Thai agriculture and Cooperatives, 1992, p.29).

Thai agricultural cooperatives may be regarded as windows into Thai agriculture. Providing access to information from outside the world for Thai farmers and information about Thai agriculture for people interested in the industry. As well as for farmers, Agricultural cooperatives provide information about the marketing of agricultural produce, more information, especially marketing information, might improve the financial income of Thais working in agriculture. This notion is supported by The Nation newspaper (1998a), which suggests that market information, such as product prices, could assist farm planning and protect farmers from unfair trading practices by merchants. Furthermore merchants could use such information to better calculate their investments and improve their business planning.

Information technology may be used by agricultural cooperatives to acquire better and more timely information. Similarly, as noted in The Nation newspaper (1998b), the Thai government could use information technology to better support the Thai farming community. As a tool for communication with and from farmers (ie. agricultural cooperatives), the 
government could be better informed of farmers' needs, and so provide better and more useful services. In a similar vein, Sirimance (1998) suggests that information technology could reduce the communication gap between rural communities and the cities.

Despite the apparent advantages, Thai agriculture, including agricultural cooperatives, has been slow to introduce and exploit information technology and this is basis of our research project. The paper contains a review of relevant literature, a discussion of the research concept and an overview of the research methodology.

\section{$1 \quad$ Literature Review}

Information technology has been used in both developed and developing countries to support operational, tactical, and strategic processes within organizations (Abdulgader \& Kozar 1995) and in most case some organizations are faster to introduce information technology than others. In our research situation, Thai agricultural cooperatives were slow introducers of information technology.

Key aspects of the literature and our research approach included:

1. Thai agricultural cooperatives,

2. Difficulties associated with information systems research,

3. Relationship between information technology \& organizations,

4. The significant of this research,

5. Previous research models and development of a new model,

6. Research questions and hypothesis,

\subsection{Thai Agricultural Cooperatives}

Agricultural cooperatives are a type of "cooperative society", a term defined by the department of fair trading as "a business undertaking owned and controlled by its members, and formed to provide them with work or with goods at advantageous prices" (Department of fair trading, 1998).

Thai agricultural cooperatives are registered with the Thai government and owned by Thai farmers. There are at present 3,344 agricultural cooperatives with a total membership of approximately 4,659,070 farmers (Cooperatives Promotion Department, Ministry of Thai agriculture and cooperatives 1999, pp.1). A board of directors elected by its members administers each cooperative. The board of directors appoints a manager and employees.

According to the Cooperatives Promotion Department of the Thai Ministry of Agriculture and Cooperatives (1993), Thai agricultural cooperatives perform, four main activities for members:

1. Provision of credit for the purchase of agricultural supplies and farm machinery.

2. Supply and sale of agricultural necessities and consumer goods.

3. Marketing of agricultural produce through local markets, provincial and national federations, and abroad.

4. Provision of agricultural extension services.

\subsection{Difficulties Associated with Information Systems Research}

Lakhanpal (1994) observed that in the past, researchers attempted to use theories from single disciplines to explain the complex relationship between information technology and 
organizations. He suggested that a multidisciplinary approach was necessary to gain a comprehensive understanding of the phenomenon. Lowry (1997, pp.192) states that:

"Information systems research is difficult because it always involves people, technology, and the linkages and interactions between them. If we remove the technology, we are no longer studying information systems but are working in reference disciplines such as psychology, sociology, human communication, organizational behavior, philosophy, epistemology, ethics, logic, anthropology, and theology. Similarly, if we remove the human aspects, we position ourselves in computer science, electronic engineering, communication technologies, physics, chemistry, and other technological reference disciplines."

Multi disciplining approaches are advantaged and used in our research.

\subsection{Information Technology \& Organizations}

Yap (1986) explains that it is difficult to establish the true relationship between information technology and organizations. As illustrated in figure 1 (below), he suggests that organizational factors may determine the use of information technology or the use of information technology may influence the organization, or some combination of both. One approach is to look at the organizational characteristics, which affect the use of information technology in order to understand why some organizations invest heavily in information technology, while others spend relatively little. On the other hand, by looking at the use of information technology and its affect on the organizational characteristics, research aims to understand how and what the organization changes such as actors (their number of employees, skills, attitude, and activities), in performance, and definition of task.

Knowledge of the underlying organizational factors affecting the use of information and the impact of information technology on organizations are not only of academic interest, but may also identify the way in which organizations benefit from information technology.

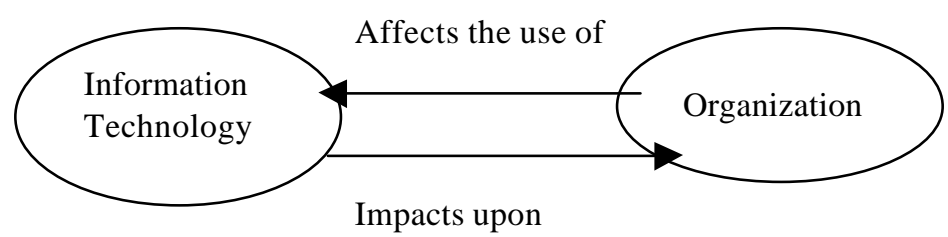

Figure 1: A conceptual model of the relationship between information technology and organizational characteristics applied from Yap (1986 pp.67).

Many theories and models have been used by researchers to explain the interrelationship of information technology and organizations. Robey \& Zmud (1992), mention the following models:

1. The political conflict model, which introduces the concept of multiple objectives, held by different interest groups or stakeholders.

2. The organizational ecology model, which views organizational form as a result of external controls rather than proceeding from the decisions or preferences of organizational members.

3. The managerial innovation model, which argue that the adoption of new technology depends on awareness of problems and organizational culture that encourage risk-taking.

4. The diffusion of innovations model, which argues that the spread of new technology depends on their application to the with work context. 


\subsection{Significance of this Research}

Investigation of technology innovation and adoption, including information technology, in developed nations is extensive (Fink 1998, Gover \& Goslar 1993, Hebert \& Benbasat 1994, Julien \& Ramond 1994, Lakhanpal 1994, Lawrence \& Keen 1996, Raymond 1990, Straub 1994, Wierenga \& Ophuis 1997). In developing countries, however, there has been little investigation and, perhaps significantly, what work has been undertaken is mostly by Western researchers.

Yap, Thong \& Raman (1994), Thong \& Yap (1995) and Thong (1996 and 1999) document information technology adoption in Southeast Asia. One finding is that key variables found in developed nations may be different from those in developing nations. In a similar vein, Robey \& Rodriquez-Diaz (1989) assert that culture can impede the implementation of information systems because of differences in the way the systems are interpreted and understood. This research investigated the factors affecting the use of information technology Thailand, with a particular focus on Thai agricultural cooperatives. It aims to confirm and improve existing theories and research methodologies, and to encourage the use of information technology in Thai agricultural cooperatives.

\subsection{Research Models}

Thong \& Yap (1995), Thong (1999) note that the use of information technology is a form of technological innovation. Lakhanpal (1994) reviewing the literature on innovation in organizations and developed the framework in figure 2 (below). It consists of the following four categories of relevant factors:

1. Individual level factors (individual innovator as well as leader and individual in key positions)

2. Organizational factors

3. Environment factors

4. Characteristics of the innovation itself.

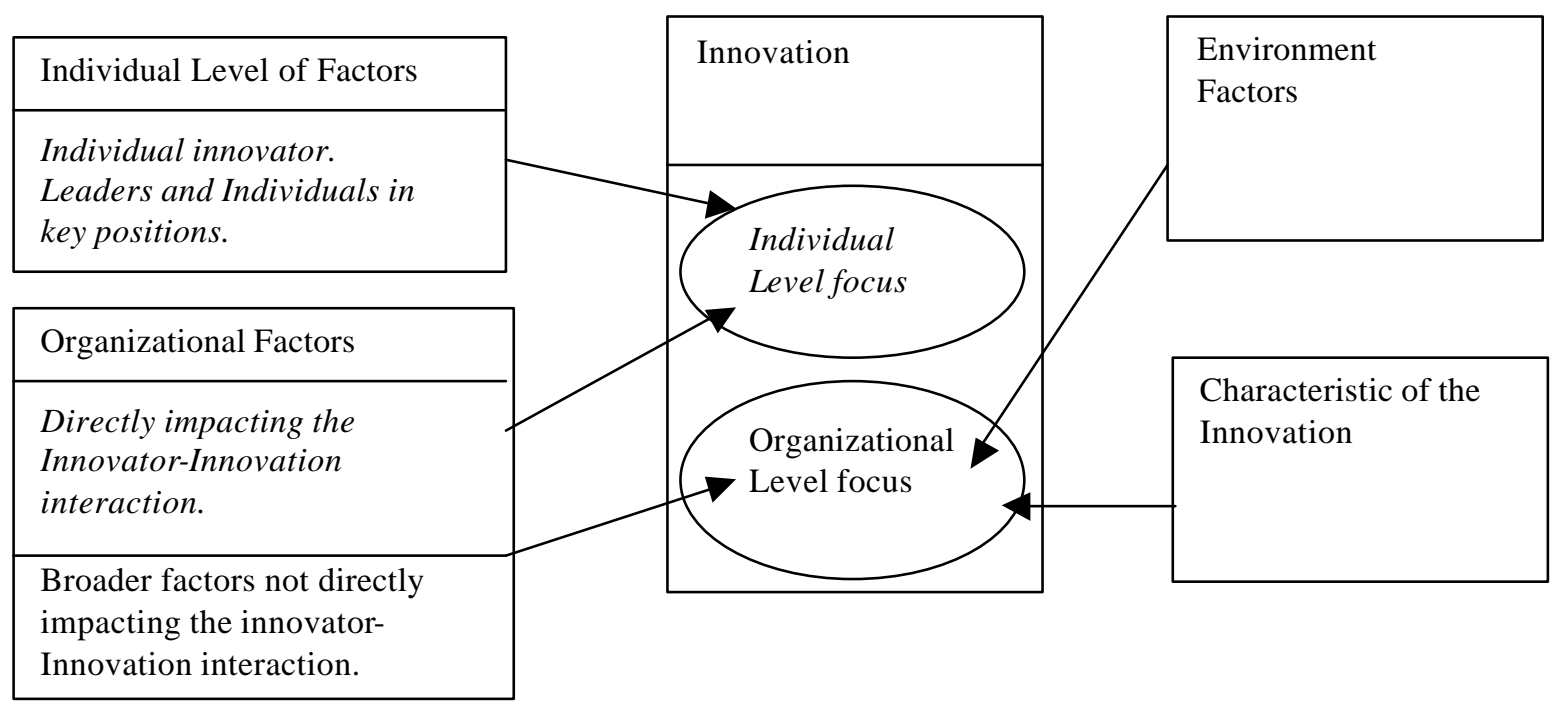

Figure 2: Factors from the innovation research tradition. Lakhanpal, B. (1994, pp.41).

\section{Individual and organizational level factors}

Individual level analyses investigate variables from two categories in Lakhanpal's framework (see figure 2); 
1. Factors belonging to the individuals involved in the innovation process (both the innovator as well as leaders and other key positions), and

2. A sub-set of organizational factors that directly affect the individual innovator's interaction with innovation.

Organizational level analyses, on the other hand, address the following (see Yap 1990, Julien \& Raymond 1994, Hebert \& Benbasat 1994 and Wierenga \& Ophuis 1997);

1. Broader organizational factors that do not directly affect the individual adopter's interaction with the innovation,

2. Environmental factors, and

3. Characteristics of the innovation.

Thong \& Yap (1995) responded on a study of individual and organizational factors within small businesses in Singapore where they studied three characteristics of chief executive officers (attitude toward adoption of IT, IT knowledge, and innovativeness), and three characteristics of organizations (business size, competitiveness of environment, and information intensity). Figure 3, below, is the model used by Thong \& Yap (1995). It is also the basis for the research project described in this paper.

CEO Characteristics

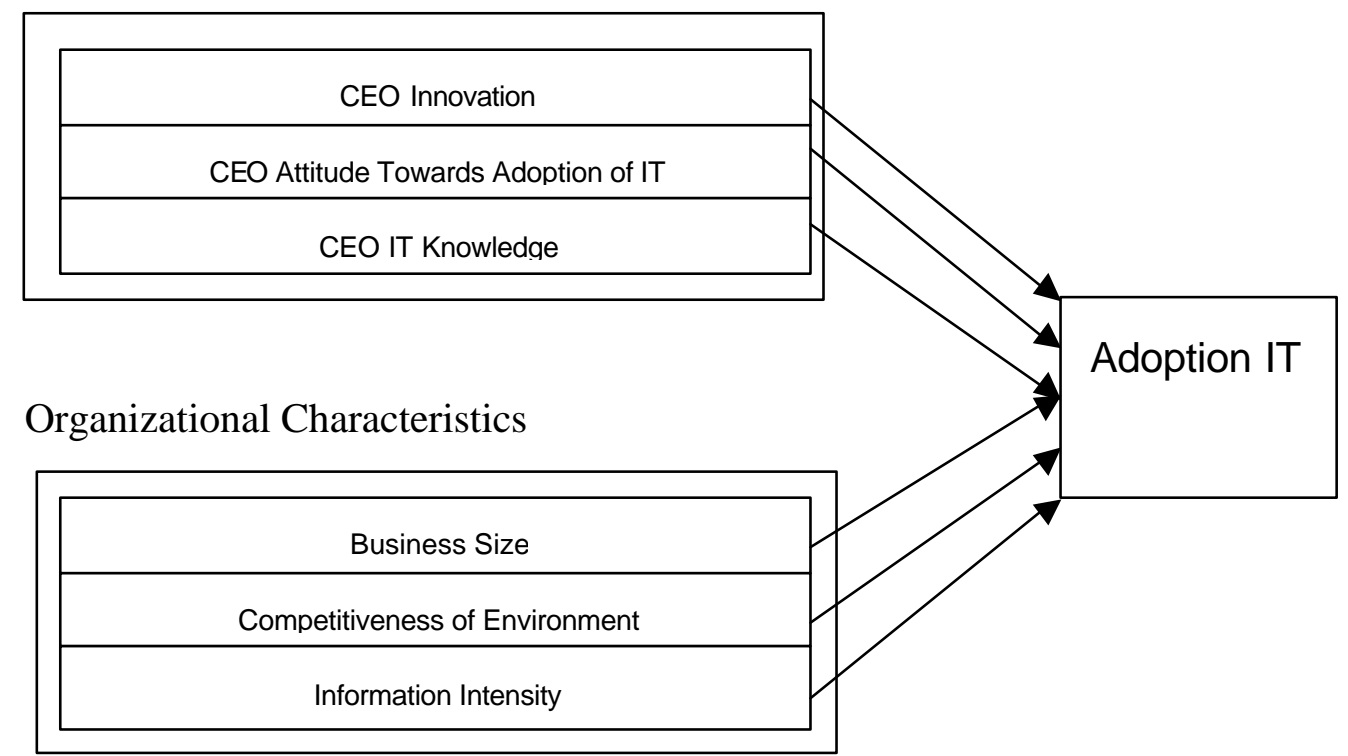

Figure 3: CEO characteristics, organizational characteristics and information technology adoption in small businesses (adapted from Thong \& Yap (1995, pp.431))

Interestingly, Thong \& Yap (1995) demonstrated that competitiveness in the environment and information intensity do not significantly influence the adoption of information technology by small businesses. As will be discussed later in this paper, neither factor will be investigated in the current study. Raymond (1990) notes that both individual and organizational factors can be important for the success of information systems within organizations.

\section{Environment factors}

Environmental factors are the third category of factors in Lakhanpal's framework (see figure 2, above). Calling them "external" factors (ie. factors outside the control of organizations and business owners), Yap (1986 and 1990) explains that there are two levels; "general" and 
specific". General external factors include social, economic, political, legal and cultural factors; and specific external factors include customers, suppliers and competitors.

Johnson \& Scholes (1993), Fry \& Stone (1995), Hunger \& Wheelen (1996), and Colthard, Howell \& Clarke (1996) all identify four general external factors; political, economic, social, and technological. However, because Thailand may be classified as a developing country, in this study, economic and technological (ie. infrastructure) factors will be given greatest emphasis. Bazar, Ulaan \& Boalch (1998) note that, in developing countries, there might be little technological infrastructure. The initial investment required for the introduction of information technology in developing countries will, therefore, tend to be high, and the adoption rate low. Yap (1986), Grover \& Goslar (1993) and Fink (1998) are examples of studies into specific external factors influencing the use of information technology in organizations.

The model in Figure 4, below, has been developed for the purposes of the study described in this paper. The model is based upon the work of Yap (1986), Thong \& Yap (1995), Johnson \& Scholes (1993), Fry \& Stone (1995), Hunger \& Wheelen (1996), and Colthard, Howell \& Clarke (1996).

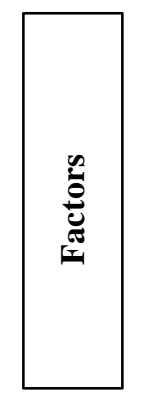

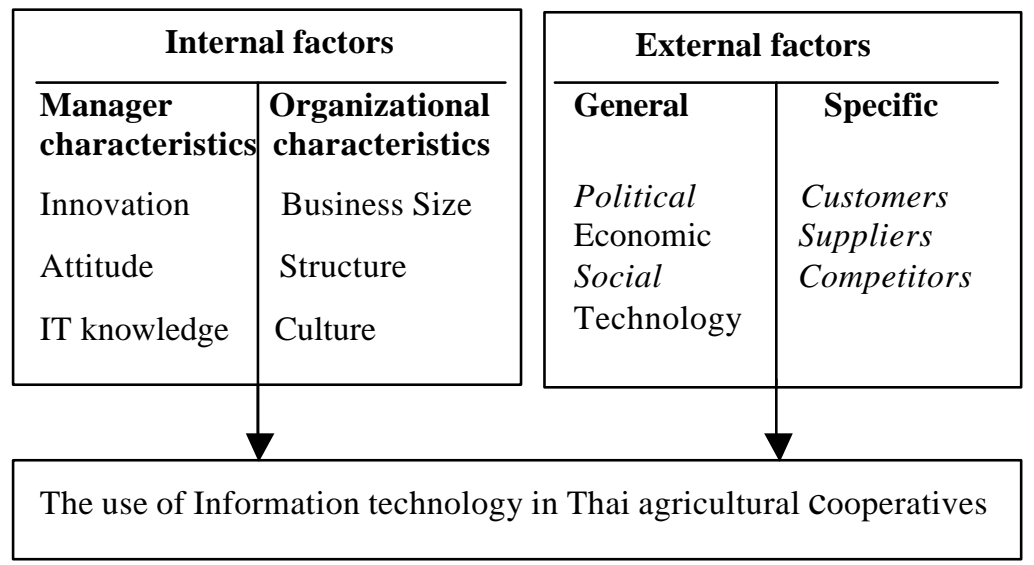

Figure 4: conceptual research model of factors affecting the use of information technology in Thai agricultural cooperatives (nb. only factors and independent variables written in regular letters will be investigated)

\section{Characteristics of the Innovation}

The fourth category in Lakhanpal's framework (see figure 2, above) is characteristics of the innovation itself. Rogers (1983) works on a diffusion of innovation theory is the seminal references in this area and he identifies characteristics of the innovation that can influence its adoption by a business. However, to fully appreciate this theory a researcher must understand all the factors that make up diffusion.

Diffusion is defined by Rogers $(1983$, p10) as " the process by which an innovation is communicated through certain channels over time among the members of a social systems"

An innovation, which maybe a process, object, or idea, must be perceived as being a new by an individual or an organization. Rogers uses the terms technology and innovation synonymously, but explains that technology is "a design for instrumental action that reduces the uncertainty in the cause-effect relationships involved in a desired outcome" (1983, pp.12)

There are 5, potentially relevant, characteristics of the innovation noted by Rogers (1983) which are potentially valuable in explaining the results of our research. 
1. Relative advantage is the degree to which a new idea is perceived as better or worse than the one it supersedes.

2. Compatibility is the degree to which an innovation is perceived as consistent with the existing values, past experiences, and needs of potential adopters.

3. Complexity is the degree to which an innovation is perceived as easy or difficult to understand and use.

4. Trialability is the degree to which an innovation may be experimented with by potential users on a limited basis.

5. Observability is the degree to which the results of an innovation are visible to others.

\subsection{Research Questions and Hypotheses}

The objective of this research project is to find answers to the following questions:

1. What factors affect the use of information technology in Thai agricultural cooperatives?

2. What characteristics differentiate Thai agricultural cooperatives that use information technology from those that do not?

3. Can an improved model be developed to explain the factors affecting the use of information technology in Thai agricultural cooperatives?

To establish a methodological foundation for the project, these research questions have been developed into the 8 hypotheses (see table 1, below). Hypotheses 1 to 6 relate to internal factors and hypotheses 7 and 8 to environmental factors (see figure 2, above). Further, hypotheses 1 to 3 concern individual level factors (ie. characteristics of the managers of Thai agricultural cooperatives), and hypotheses 4 and 6 concern organizational level factors. 


\begin{tabular}{|c|c|c|}
\hline 1 & $\begin{array}{l}\text { Thai agricultural cooperatives } \\
\text { with managers who are } \\
\text { innovative are more likely to use } \\
\text { information technology. }\end{array}$ & $\begin{array}{l}\text { Thong \& Yap (1995) and Thong (1996 and 1999) found } \\
\text { that firms are more likely to adopt information } \\
\text { technology when their CEOs are more innovative. }\end{array}$ \\
\hline 2 & $\begin{array}{l}\text { Thai agricultural cooperatives } \\
\text { with managers who have more } \\
\text { positive attitude towards the use } \\
\text { of information technology are } \\
\text { more likely to use information } \\
\text { technology. }\end{array}$ & $\begin{array}{l}\text { Lakhanpal (1994), found that a middle manager's } \\
\text { attitude towards microcomputer usage had a relatively } \\
\text { positive influence on the adoption of microcomputers. } \\
\text { Also Thong \& Yap (1995) assert that CEOs who possess } \\
\text { a positive attitude towards information technology are } \\
\text { more likely to adopt information technology in their } \\
\text { business. }\end{array}$ \\
\hline 3 & $\begin{array}{l}\text { Thai agricultural cooperatives } \\
\text { with managers who are more } \\
\text { knowledgeable about } \\
\text { information technology are } \\
\text { likely to use information } \\
\text { technology }\end{array}$ & $\begin{array}{l}\text { Boynton, Zmud \& Jacobs (1994) found that managerial } \\
\text { information technology knowledge is a dominant factor } \\
\text { in explaining the high level of information technology } \\
\text { use in organizations. Similarly, Cragg \& King (1993) } \\
\text { note that the strongest factor inhibiting firms from } \\
\text { adopting is a lack of knowledge of owners. }\end{array}$ \\
\hline 4 & $\begin{array}{l}\text { Thai agricultural cooperatives } \\
\text { that have a large in business size } \\
\text { are more likely to use } \\
\text { information technology. }\end{array}$ & $\begin{array}{l}\text { Thong \& Yap (1995) found that business size is the most } \\
\text { significant discriminator in determining the use of } \\
\text { information technology. Wierenga \& Ophuis (1997) note } \\
\text { that the size of organizations is positively related to } \\
\text { adoption and innovation. }\end{array}$ \\
\hline 5 & $\begin{array}{l}\text { Culture of Thai agricultural } \\
\text { cooperatives influences the use } \\
\text { of information technology in } \\
\text { firms. }\end{array}$ & $\begin{array}{l}\text { Burn, Davison \& Jordan (1997), Straub (1994) found } \\
\text { that that information technology adoption and use } \\
\text { depends strongly upon organizational culture. Similarly, } \\
\text { a research project conducted in Thailand by Vimoktanon } \\
\& \text { Piyawan,(1994) found that a significant factor for } \\
\text { adopting the use of information technology in an } \\
\text { organization was the organizational culture. Using a } \\
\text { computer in organizations indicated that the image of } \\
\text { management was good. }\end{array}$ \\
\hline 6 & $\begin{array}{l}\text { The structure of Thai } \\
\text { agricultural cooperatives } \\
\text { influences the use of } \\
\text { information technology in firms. }\end{array}$ & $\begin{array}{l}\text { Grover, Goslar \& Segars }(1995) \text { found that } \\
\text { organizational structure and centralization influence } \\
\text { organizations to adopt telecommunication technology. }\end{array}$ \\
\hline 7 & $\begin{array}{l}\text { Thai agricultural cooperatives } \\
\text { are influenced to use } \\
\text { information technology by } \\
\text { economic conditions in the } \\
\text { country as a whole. }\end{array}$ & $\begin{array}{l}\text { The National Science and Technology Development } \\
\text { Agency (1997) reported that the economic crisis in } \\
\text { Thailand affected not only the government sector, but } \\
\text { also the business sector. This means that any kind of } \\
\text { business in Thailand, including agricultural } \\
\text { cooperatives, might be affected by an economic crisis. }\end{array}$ \\
\hline 8 & $\begin{array}{l}\text { Thai agricultural cooperatives } \\
\text { are influenced to } r \text { use } \\
\text { information technology by } \\
\text { Infrastructure. }\end{array}$ & $\begin{array}{l}\text { The National Science and Technology Development } \\
\text { Agency (1997) reported that the communication } \\
\text { infrastructure in rural areas of Thailand is still poor and } \\
\text { needs improvement. Also Potipattanakorn (1997) noted } \\
\text { that, in Thailand, one of the problems for the retail } \\
\text { sector is inefficient and inadequate telecommunications }\end{array}$ \\
\hline
\end{tabular}

Table 1- Research hypotheses and associated findings from the literature 


\section{$2 \quad$ Research Methodology}

Previous questionnaire developed from western culture and adopted for Singaporean Chinese studied by Thong \& Yap (1995), Thong (1996) and current questionnaire translated and adopted for Thai. This section describes development of the variables, questionnaire, and its testing.

\begin{tabular}{|c|c|c|}
\hline Independent variables & Measurement & References \\
\hline \multicolumn{3}{|l|}{ Manager characteristics } \\
\hline Manager innovation: & $\begin{array}{l}\text { Innovative } \\
\text { Not innovative }\end{array}$ & Kirton 1976 \\
\hline $\begin{array}{l}\text { Manager attitude to the use of } \\
\text { Information Technology }\end{array}$ & $\begin{array}{l}\text { Positive attitude forward using of } \\
\text { information technology } \\
\text { Negative attitude forward using of } \\
\text { information technology }\end{array}$ & Moore \& Benbasat 1991, \\
\hline $\begin{array}{l}\text { Manager's Information Technology } \\
\text { knowledge }\end{array}$ & $\begin{array}{l}\text { More knowledge } \\
\text { Less knowledge }\end{array}$ & $\begin{array}{l}\text { Thong \& Yap 1995, Thong } \\
\text { 1996, Thong } 1999\end{array}$ \\
\hline \multicolumn{3}{|l|}{ Organizational characteristics } \\
\hline Business Size: & $\begin{array}{l}\text { Number of employees } \\
\text { And budget }\end{array}$ & $\begin{array}{l}\text { Wierenga \& Ophuis 1997, } \\
\text { Thong \& Yap 1995, Thong } \\
\text { 1999, Raymond 1990 }\end{array}$ \\
\hline Structure & $\begin{array}{l}\text { Formalization } \\
\text { Centralization }\end{array}$ & Yap (1986 and 1990) \\
\hline Culture & $\begin{array}{l}\text { process oriented vs. results oriented } \\
\text { employee oriented vs. job oriented } \\
\text { parochial vs. professional } \\
\text { open system vs. closed systems } \\
\text { loose vs. tight control } \\
\text { normative vs. pragmatic }\end{array}$ & $\begin{array}{l}\text { Hofstede } 1991, \text { Hofstede } 1993, \\
\text { Hofsted } 1998\end{array}$ \\
\hline
\end{tabular}

\section{External environment of organizations}

\begin{tabular}{|l|l|l|}
\hline Economic & $\begin{array}{l}\text { Perception and awareness of managers } \\
\text { to the economy }\end{array}$ & $\begin{array}{l}\text { Johnson \& Scholes (1993), Fry } \\
\& \text { Stone (1995), Hunger \& } \\
\text { Wheelen (1996), Colthard, } \\
\text { Howell \& Clarke (1996). }\end{array}$ \\
\hline Infrastructure & $\begin{array}{l}\text { Perception and awareness of managers } \\
\text { to infrastructure }\end{array}$ & $\begin{array}{l}\text { Johnson \& Scholes (1993), Fry } \\
\text { \& Stone (1995), Hunger \& } \\
\text { Wheelen (1996), Colthard, } \\
\text { Howell \& Clarke (1996). }\end{array}$ \\
\hline
\end{tabular}

\section{Dependent variable}

\begin{tabular}{|l|l|l|}
\hline Use of Information Technology & $\begin{array}{l}\text { The use of information technology is } \\
\text { divided into 2 level. } \\
\text { Non use } \\
\text { Use (light or intensive) }\end{array}$ & $\begin{array}{l}\text { Yap 1986, Thong \& Yap 1995, } \\
\text { Thong 1996 }\end{array}$ \\
\hline
\end{tabular}

Table 2: Variables in the study of factors affecting the use of information technology in Thai agricultural cooperatives.

As discussed previously, and illustrated in Figure 3 (above), Thong \& Yap (1995) demonstrated that competitiveness of environment and information intensity do not significantly influence the adoption of information technology by small businesses. Neither factor, therefore, is being investigated in this study. In their place will be studied organizational structure and organizational culture. 
Data collection used a questionnaire mailed to managers of Thai agricultural cooperatives. Following the arguments of Sarantakos (1998), the questionnaire employs a five point Likert scale representing a range from "Strongly Disagree" to "Strongly agree" (other examples of information systems researchers who used Likert scales are $\mathrm{Ng}$, Tye \& Chau (1994), Thong \& Yap (1995), Thong (1996 and 1999), Gover, Goslar \& Segars (1995).

Pretesting and Piloting was used to refine the questionnaire. This was done in semi structure ways that enable discussion to occur on complex or misunderstand questions. Sarantakos (1998) and Lawrence \& Keen (1996) recommended this is a way of improving question wording.

During the pretest three groups were interviewed; the head of Information Technology Section, Ministry of Thai Agricultural Cooperatives; two Thai researchers; and five Thai agricultural cooperative managers.

One problem encountered by Thai agricultural cooperatives using information technology is a lack of relevant knowledge. Most of the employees in agricultural cooperatives who operate the computers is that they have no education in information technology or related disciplines. However, even though, the Ministry of Agricultural Cooperatives spend money on training, employees with useful skills and knowledge, these are inclined to work in private companies where they get more pay.

Development and promotion of software by the Ministry of Thai Agriculture and Cooperatives has been successful, but there has been a lack of interaction between systems analysts and cooperative managers who have not adequately defined their requirements. The existence of these types of problem is supported by the Thailand Development Research Institute Foundation (1997), Malaiwong (1999a), Malaiwong (1999b).

After pretesting and modifying questions and the format, reliability was evaluated by sending questionnaires to 20 randomly selected managers of Thai agricultural cooperatives. 14 questionnaires were returned of which 4 were not answered completely.

Reliability, according Sarantakos (1998), refers to the ability of an instrument to produce consistent results. Reliability is equivalent to consistency.

Hair (1998) notes that Coefficient alpha, ranging between 0 to 1 is frequently used to estimate reliability when the instruments developed by rating scales. Nunnally (1967) cited in Thong, Yap (1995) notes that a reliability of 0.5 to 0.6 is sufficient for early stages of basic research. Some examples of reliability of variables in this study are, 0.88 for manager innovative, 0.73 for attitude forwards computerization, 0.76 for economic, and 0.76 for infrastructure, so we are confident of our scale at this stage of the analysis.

There are 3,398 Thai agricultural cooperatives with 4,659,373 members (Cooperatives Department promotion, Ministry of Thai Agriculture and Aooperatives,1999, pp.1). Sproull (1995) notes that for sampling purposes there is no statistical rationale for using an arbitrarily selected percentage of the population. Some researchers arbitrarily decide to use a 5\% or $10 \%$ sample of population. In this research, a $10 \%$ sample, or 340 cooperatives, of the population was used. The data analysis and statistical techniques used in this project will include both descriptive and inferential methods and will follow the work of Thong \& Yap (1995) and Thong (1996 \& 1999). 


\section{Conclusion}

This project aims to test and improve existing theories and methodologies in the research of information systems adoption in the Thai agricultural cooperatives. It also attempts to improve industry practice where agricultural organizations in nations like Thailand can learn and adapt to changes.

Thai agriculture, notably agricultural cooperatives, has been slow to introduce and exploit information technology. To discover why, and to understand the relationship between information technology and Thai agricultural cooperatives, it is necessary to draw from disciplines such as information systems and social science.

Quantitative techniques were used to investigate. Factors in the external and internal environment of organizations. Factors in the external environment like the national economy and infrastructure were also considered. Also factors in the internal environment of Thai agricultural cooperatives, analysis of organizations and individuals. Such as business size, organizational culture and structure, and individual factors include manger innovation, attitude towards information technology, and information technology knowledge were also investigated.

\section{Appendix A}

An example of questionnaire

Previous questionnaire developed for western culture and adopted for Singaporean Chinese Studied by Thong \& Yap (1995), Thong (1996).

\section{Attitude toward Computerization}

This section aims to evaluate your (CEOs) attitude towards computerization. Please read the following statements carefully and for each statement, circle a number from 1 to 5 which best describes your views on the statements.

\begin{tabular}{lccccc} 
& Strongly Disagree & \multicolumn{2}{c}{ Strongly Agree } \\
Computerization improves the quality of & 1 & 2 & 3 & 4 & 5
\end{tabular}

Work in my organization.

Current questionnaire translated and adopted for Thai.

\begin{tabular}{|c|c|c|c|c|c|}
\hline \multirow{3}{*}{\multicolumn{6}{|c|}{$\begin{array}{l}\text { Attitude toward Computerization } \\
\text { Please indicate the extent to which you are satisfied with each of the } f \\
\text { appropriate number. } \\
\text { The meaning of the number } \\
\text { 1) Strongly Disagree, 2) Disagree, 3) Fair, 4) Agree, 5) Strongly agree }\end{array}$}} \\
\hline & & & & & \\
\hline & & & & & \\
\hline \multirow[t]{2}{*}{ Items } & \multicolumn{5}{|c|}{ Level of your opinion } \\
\hline & 1 & 2 & 3 & 4 & 5 \\
\hline Computerization improves the quality of work ................ & $\ldots$ & $\ldots$ & $\ldots$ & $\ldots$ & $\ldots$ \\
\hline
\end{tabular}




\section{References}

Abdulgader, A.H. \& Kozar, K.A. (1995). The Impact of Computer Alienation on Information Technology Investment decisions: An Exploratory Cross-National Analysis. MIS Quaterly, Vol. 19 (4), 535-559.

Bazar, B., Bataar, U. \& Boalch, G. (1998). A Preliminary Model of Internet Diffusion within Developing Countries. AUSWEB97 Version 4.05. http://ausweb.scu.edu.au/proceedings/ boalch/paper.html

Boynton, A.C., Zmud, R.W. \& Jacob, G.C. (1994). The Influence of IT Management Practice on IT Use in Large Organizations, MIS Quarterly, 18, 3, 299-318.

Burn, J., Davison, R. \& Jordan, E. (1997). The Information Society -A Cultural Fallacy?. Journal of Failures and Lessons Learned in IT Management, 1, 4, 219-232.

Cooperatives Promotion Department (1993), Cooperatives in Thailand. Bangkok: Thai Ministry of Agriculture and Cooperatives.

Cooperatives Promotion Department (1999), Annual Report of Cooperatives in Thailand. Bangkok: Thai Ministry of Agriculture and Cooperatives.

Coulthard, M., Howell, A. \& Clarke G. (1996). Business Planning: The Key to Success. Macmillan Education Australia: South Melbourne.

Cragg, P.B \& King M. (1993). Small-firm computing: Motivators and Inhibitors. MIS Quarterly, 17, 1, 47-60.

Department of Fair Trading, NSW Consumer Protection Agency (1998). A Guide to Cooperatives. http://www.peg.apc.org/ coopsnsw/guide.htm

Fink, D. (1998). Guidelines for Successful Adoption of Information Technology in Small and Medium Enterprise. International Journal of Information Management, 18, 4, 243-253.

Fry, F.L. \& Stoner, C.R. (1995). Strategic Planning for the New Small Business. Upstart Pub. Co: Dover, N.H.

Gover, V. \& Goslar, M. D. (1993). The Initiation, Adoption, and Implementation of Telecommunications Technologies in U.S. Organizations. Journal of Management Information Systems, 10, 1, 141-163.

Gover, V., Goslar, M. \& Segars, A. (1995). Adopters of Telecommunications Initiatives: A Profile of Progressive US Corporations. International Journal of Information Management, 15, 1, 33-46.

Hair, J.F. (1998). Multivariate Data Analysis. Uppper Saddle River, N.J., Prentice Hall.

Hebert, M. and Benbasat, I. (1994) Adopting Information Technology in Hospitals: The Relationship between Attitudes/Expectations and Behavior, Hospital \& Health Services Administration, 39, 3, 369-384. 
Hofstede, G. (1991). Cultures and Organizations: Software of the mind. Mc Graw-Hill: Berkshire.

Hofstede, G. \& Bond, M.H. (1993). Individual Perceptions of Organizational Cultures: A Methodological Treatise on Levels of Analysis. Organization Studies, 14, 4, 485-503.

Hofstede, G. (1998). Attitudes, Values and Organizational Culture: Disentangling the Concepts. Organization Studies, 19, 3, 472-492.

Hunger, D. \& Wheelen, T.L. (1996). Strategic Management. $5^{\text {th }}$ ed. Addison-Wesley Pub.Co: Reading, MA.

Johnson, G. \& Scholes, K. (1993). Exploring Corporate Strategy. $3^{\text {rd }}$ ed. Prentice Hall: New York.

Julien, P.A. \& Raymond, L. (1994). Factors of News Technology Adoption in the Retail Sectors. Enterpreneurship Theory \& Practice, 18, 4, 79-90.

Kirton, M. (1976). Adaptors and innovators: a description and measure. Journal of Applied Psychology, 61, 5, 622-629.

Lakhanpal, B. (1994) Assessing the Factors Related to Microcomputer Usage by Middle Managers, International Journal of Information Management, 14, 1, 39-50.

Lawrence, K.L. \& Keen, C.D. (1996). A Survey of Factors inhibiting the Adoption of Electronic Commerce by Small and Medium Enterprises in Tasmania. Working Paper WP 97-01. Department of Information Systems. University of Tasmania.

Lowry, R.G. (1997). Postgraduate research training for information systems: improving standards \& reducing uncertainty. $8^{\text {th }}$ Australian Conference on Information Systems.

Mahidol University, agriculture, http://www.mahidol.ac.th/Thailand/economy/agricult.html

Malaiwong, K. (1999a). The Future of Thai Information Technology Students during the Economic Crisis. National Electronics and Computer Technology Center: Thailand.

Malaiwong, K. (1999b). Using Information Technology to Solve the Economic Crisis. National Electronics and Computer Technology Center: Thailand.

Moore, G.C. \& Benbasat, I. (1991). Development of an Instrument to Measure the Perceptions of Adopting and Information Technology Innovation. Information Systems Research, 2, 3, 192-222.

Ng Tye, E.M.W. \& Chau P.Y.K (1995). A Study of Information Technology Adoption in Hong Kong, Journal of Information Science, 21, 1, 11-19. 
Office of Agricultural Economics, Ministry of Thai Agricultural Cooperatives (1992). Agriculture in Thailand (A Commemoration Edition on the Occasion of the Centennial Anniversary)

Raymond, L. (1990). Organizational Context and Information Systems Success: A Contingency Approach, Journal of Management Information Systems, 6, 4, 5-20.

Robey, D. \& Rodriguez-Diaz, A. (1989). The Organizational and Cultural Context of Systems Implementation: Case Experience from Latin America. Information and Management, 17, 4, 229-239.

Robey, D \& Zmud, R. (1992). Research on the Organization of End-User Computing: Theoretical Perspectives from Organization Science, Information Technology \& People, 6, 1, 11-27. .

Rogers, E.M. (1983). Diffusion of Innovations, $3^{\text {rd }}$ ed. Free Press: New York.

Sarantakos, S. (1998). Social Research, $2^{\text {nd }}$ ed. Charles Sturt University: Australia.

Sirimance, S. (1998) The Information technology Revolution: What about the developing countries?, International Development Information Center. http://www.acdicida.gc.ca/xpress/dex/dex $9604 \mathrm{htm}$

Sproull, N.L. (1995). Handbook of Research Methods: A Guide for Practitioners and Students in the Social Sciences, $2^{\text {nd }}$ ed. The Scarecrow Press: London.

Straub, D.W. (1994). The Effect of Culture on IT Diffusion: E-Mail and FAX in Japan and the U.S. Information Systems Research, 5, 1, 23-47.

Thailand Development Research Institute Foundation (1997). The Analysis of the possibility of developing information technology infrastructure in Thai government.

The Nation newspaper (1998a). Help for Farmers, Byteline: Information technology Thailand. http://www.nationamultimedia.com/byteline/byteline/stories/0951/st1.html

The Nation newspaper (1998b). IT comes to rural community, Technology. http://www.nationamultimedia.com/news/ruralnet2.html

The National Science and Technology Development Agency (1997). What Thailand needs to survive. http://www.nstda.or.th/newsroom/pr/pr241097a.html

Thong, J.Y.L. (1996). Information systems adoption and implementation in small businesses in Singapore. PhD thesis, National University of Singapore.

Thong, J.Y.L (1999). An Integrated Model of Information Systems Adoption in Small Businesses, Journal of Management Information Systems, 15, 4, 187-214.

Thong, J.Y.L \& Yap, C.S. (1995). CEO Characteristics, Organizational Characteristics and Information Technology Adoption in Small Business, Omega-International Journal of Management Science, 23, 4, 429-442. 
Vimoktanon B. \& Piyawan P.(1994). The Use of Computer for Accounting in Five Star Hotels in Bangkok, Chulalonkon Varasan, 3, 12, 86-91.

Wierenga, B. \& Ophuis, P.A.M.O. (1997). Marketing Decision Support Systems: Adoption, Use, and Satisfaction, International Journal of Research Marketing, 14, 275-290.

Yap, C.S. (1986). Information Technology in Organizations in the service sector. PhD thesis, University of Cambridge.

Yap, C.S. (1990). Distinguishing Characteristics of Organizations Using Computers. Information \& Management, 18, 97-107.

Yap, C.S., Thong, J.Y.L. \& Raman, K.S. (1994).Effect of Government Incentive on Computerization in Small Business, European Journal of Information Systems, 3, 3, 191-206.

\section{Authors's Biographies}

Oran Chieochan has a Bachelor of Science (Hons) degree from Rajamangala Institute of Technology, Thailand, a Master of Computing degree from Griffith University, Australia, and is currently studying towards a Ph.D. in the School of Information Studies, Charles Sturt University, Australia. His research interests focus on information technology in agricultural businesses and rural development in developing countries.

David Lindley has degrees in computing and information management and a Ph.D. from the University of New South Wales, Australia. He has approximately 15 years industrial experience and is presently an academic in the School of Information Studies, Charles Sturt University, Australia. He is also Chief Examiner of the Australian Computer Society and a consultant to IDP Education Australia. His principal research interest lies in the use of information technology for national economic and social development, especially in the countries of South and East Asia.

Tony Dunn has a Master of Agricultural Science from the University of Melbourne in Extension. He is a Senior Lecturer in extension and Agricultural Systems in the School of Agriculture at Charles Sturt University, Australia. His research interests are in the rural social sciences including the application of qualitative methodologies to improve agricultural use of natural resources and the social condition of rural people. Particular specialties include the application of methodologies like Soft Systems Methodology and Rapid/Participatory Rural Appraisal to assist change in rural social systems. 